\title{
The Role of the Government Policy for Support the SME-s
}

\author{
Dr. Ylvije Boriçi Kraja \\ Lecturer in Economic Faculty, \\ University of Shkodra "Luigj Gurakuqi" \\ Prof.As.Dr Elez Osmani \\ Lecturer in Economic Faculty, \\ University of Shkodra "Luigj Gurakuqi" \\ Prof.As.Dr Fatbardha Molla \\ Lecturer in Economic Faculty, \\ University of Shkodra "Luigj Gurakuqi"
}

\section{Doi:10.5901/ajis.2014.v3n2p391}

\section{Abstract}

This paper describes the important role of the government policy for support the SME-s. In Albanian economy, a transition market economy, SME-s, constitute the main source of the national income. The Albanian economy, like the other countries in our region is challenging a lot of problems. As far as we know most of the problems stem from the transition period. This paper presents the contributions of the SME-s sector to total employment. SME-s play a vital role in the economy, they have a crucial importance in developed and especially in developing countries. According Analoui \& Karami (2003), SME-s are important contributions in creation of the new jobs and in the growth of the economy. Contemporary global economy deals SME-s slowly with the impact of economic problems, that's why we want to bring here the important role that the government has to protect, to create facilities for business, making them to operate in the right ways. The aim of this study is to accent and to underline that government can change and improve the SME-s conditions with their policies. These policies could help them to performance growth and in this way lasting competitiveness in the market. To verify how much do the business feel the government support. There is done a study in one of the main cities in Albania, Shkoder. Based on the data gathered by the questionnaires, on some of the SME-s in this city, there is done an regression analysis. This analyze is done to understand the situation. Based on the results of the analyses are done conclusions and recommendations.

Keywords: government policy, SME-s, management, performance, economic growth, regression analyses.

\section{Introduction}

The SMEs are vital, and the most important sector in the economic development of the country. The SMEs play a great role to generate employement, promotion of innovation and creation of competition and a healthy economy (Bannock,1981).

Albania as a lot of other countries in the region is challanging with a bunch of difficulties. Based on the fact that we are a developing country, a country that SMEs are raised and developed in less than 23 years, certainly the lack of knowledge and experience in business can be considered as a barrier. One of the key barriers can be considered high corruption that becomes a hindrance to the normal performance of businesses. Government policy is a key factor that affects the success and performance of SMEs Hunjra (20011). For this reason it is important the government support, with programs for SMEs, in order for that to have a sustainable development of the economy. Most of the governments in the world are focused on supporting the development of SME sector, to have a stable economy (Butler, 2008).

Sometimes, the increase of the SMEs is damaged by a set of direct and direct barriers set up by local and central government. First of all, the high rates of taxes are the main barriers for the SME-s. This is the main reason that a part of the businesses try to work in the informal way.

Financial resources are one of the major sources, which are vital and very important for the success of SMEs. When these resources are accompanied and are based on business plans and marketing strategy then it will help the 
SMEs to achieve business objectives and goals.

SME-s should know which are the sources that they have and than try to turn them in the advantage for their business (Boriçi \& Osmani, 2013). Of course for this reason it is necessary to have an financial support for small and medium enterprises. Central and local government policies have impact on economic development of a country. SMEs are a great contributors in economic development, source of incomes and generate employment in a country. This study is focused on SMEs in the Shkodra City, Albania.

The aim of the study is: Evaluation of the government political role in the success of the SMEs (case of the SMEs in the Shkodra Region)

The main objectives:

- In this paper the main objective is to analyze and to evaluate the role that the local and central government has in promotion of SMEs.

- The estimated local government support for the development of new SMEs.

- To assess whether there is actually a plan to support the development of small and medium, and if they are to be analyzed and evaluated, if this plan is merely formal or applicable to current conditions.

Research question Does the local and central government affect the performance of the SMEs

Based on the research question raised is cast to be proved the hypothesis and to answer the research question.

Hypothesis: Central and local government policy affects the performance of SMEs.

The methodology of this paper consists in a combination of primary and secondary research. There is a combination of qualitative and the quantitative method. Initially are studied scientific articles and papers, as well as data from the tax offices and then is built a questionnaire to obtain information from representatives of SMEs, pertainning the policies used by local and national government.

\section{Theoretical Background}

SMEs are important not only in developed countries but also in developing countries. SMEs constitute the main source of materials, ideas, processes and services that large enterprises cannot or do not want to do (Keskin Senturk, 2010). Sultan, SS (2007) in his work expresses a summary of the political and economic gains made by Tolento (2000) for SMEs, where noted:

* create jobs to low cost of capital

* contribute positively to GDP

* create opportunities to expand the base of entrepreneurship

* provides the flexibility required to adapt the market changes;

* provides support to enterprises that have extension

* contributes to development policies that are oriented more towards decentralization and rural development.

* A successful management of SMEs needs a combination of policies and institutions: economic policies on the one hand that have the critical role and the other hand the institutions should play their role for the promotion and encouragement of SMEs.

* We have thousands of SMEs around the world being thus the most important sources of economic developments (Naghi, M 2011). Investment by SMEs are a generator of economic growth and social changes in a country's economy.

* According to Islam et. al (2011) firm's performance is linked to the success of firms in the market, which may have different results. The performance of firms is a complex one and multi-dimensional phenomenon. Performance can be characterized as the ability of firms to create acceptable results.

According to the World Bank report 'Doing Business 2012-2013' Albania is ranked 85th out of 185 economies.

Chart 1. Comparison with other countries of the western Balkans.

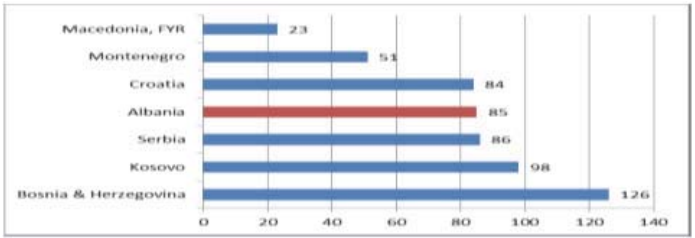

Source: 'Doing Business 2012-2013' (INSTAT) 
From year to year, Albanian SMEs have gained experience, and businesses are being consolidated. Political stability makes a country an attractive one for foreign investors despite other advantages that it can bring (Schneider Frey, 1985).

Table 1: Information on SMEs in Shkodra

\begin{tabular}{|l|c|c|c|c|c|c|}
\hline & 2011 & $\%$ në total & 2012 & $\%$ në total & 2013 & \% në total \\
\hline Small & 3138 & 68,87 & 4539 & 75,49 & 3257 & 68.78 \\
\hline Medium & 442 & 9,7 & 488 & 8,12 & 489 & 10.34 \\
\hline Large & 976 & 21,42 & 985 & 16,38 & 989 & 20.88 \\
\hline Total & 4556 & 100 & 6012 & 100 & 4735 & 10 \\
\hline
\end{tabular}

Source: The tax office (2013)-edited by author

From the above information could be seen that in 2012 compare to 2011 there was an increased number of SMEs. In 2013 comparison to 2011 there was an increased number of SMEs while pertainning to 2012 there was a decreased number of small enterprises. That mean that there were some new businesses that could not survive and could not face the challenges

\section{Analisys of Data}

In this study have been examined 220 businesses from Shkodra district. The chart below shows that $27.73 \%$ were from production sector, $37.27 \%$ of the businesses that are considered were from the service sector, $26.36 \%$ were from the trade sector and $5.91 \%$ of the businesses were construction sector and $2.73 \%$ were from other sectors.

Graph 1: Types of the activities

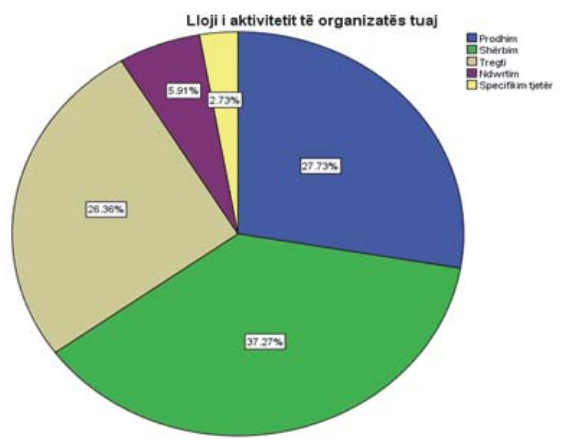

\section{Factor and Reliability Analysis}

Factor analysis is a statistical technique. Factor analysis was used to assess whether the variables are statistically independent, and this is realized to go on, to further procedure with statistical analysis. According to Hair et al,. (1998) factor analysis can also identify representative variables from a much larger set of variables, for use in subsequent multivariate analyses or create an entirely new set of variables, much smaller in number to partially or completely replace the original set of variables for inclusion in subsequent techniques. While reliability according to Hair et.al.,(1998) is an assessment of the degree of consistency between multiply measurements of a variable.

Performance of the businesses is measured as the average of the two questions, income and the ROI. For this reason for these two questions is done the factor analysis, using the method: analysis with rotation Varimax. Reliability is measured by the Cronbanch Alpha, (N 220) Cronbach alpha $=0,678$. This coefficient is acceptable for an exploratory coefficient. Cronbach Alpha is the reliability coefficient that assess the consistency of the entire scale (Hair et.al.1998). From factor analysis these two questions result in one factor which explain $75.56 \%$ of the total variance. 
Table 2: Factor analysis

\begin{tabular}{|c|c|}
\hline Performance & \\
\hline Income & 0,870 \\
ROI & 0,866 \\
\hline
\end{tabular}

Questions are measured by Likerd scale from 1. - 5 (disagree - very much agree).

Table 3: Correlation

" financial support and assistance by the government", "taxes policy " and "incubators "

\begin{tabular}{|c|c|c|c|}
\hline & $\mathbf{1}$ & $\mathbf{2}$ & $\mathbf{3}$ \\
\hline $\mathbf{1}$ & 1 & & \\
\hline $\mathbf{2}$ & $0,404^{\star \star}$ & 1 & \\
\hline $\mathbf{3}$ & $0,472^{\star \star}$ & $0,331^{\star \star}$ & 1 \\
\hline
\end{tabular}

:** Correlation is important at the 0.01 level ( 2- tailed)

As it could be seen by the table above the Pearson Correlation is acceptable to go on with the regression analysis because the values are less than 0.7 .

Table 4 : Regression analysis for dependent variable "performancë"

\begin{tabular}{|l|c|c|c|c|}
\multicolumn{1}{|c}{ Model } & $\mathbf{R}^{2}$ & $\mathbf{R}^{2}$ adjusted & \multicolumn{1}{c|}{ Sig } \\
\hline (Constant) & 0.318 & 0.308 & & \\
Financial support and assistance for SMEs by the government & & & 6.252 & 0.000 \\
Taxes policy & & & 4.972 & 0.000 \\
Incubators & & & 3.323 & 0.001 \\
\hline
\end{tabular}

$\mathrm{R}^{2}$ square is the correlation coefficient squared, $\mathrm{R}^{2}$ is 0.318 , also referred to as the coefficient of determination. This value indicates the percentage of total variation of $Y$ explained by $x_{1}, x_{2}$ and $x_{3}$.

$\hat{Y}=\beta_{0}+\beta_{1} x_{1}+\beta_{2} x_{2}+\beta_{3} x_{3}$

$\mathrm{X}_{1}=$ predictor " Financial support and assistance for SMEs by the government "

$\mathrm{x}_{2}=$ predictor " taxes policy"

$x_{3}=$ predictor " incubators"

Using the unstandardized regression coefficient, or beta, simple regression equation can be presented as follows

"performance"= 1.549+ 0.208 " Financial support and assistance for SMEs by the government " +

+0.135 " taxes policy " + 0.100 " incubators "

Coefficient of the independent variable in this case " Financial support and assistance for SMEs by the government "; " taxes policy "; and " incubators " are positive, which means the increase in the level of the independent variables it will increase in the level of the dependet variable. "performance".

Based on this analyse it results that the independents variable explain $30.8 \%$ of the variance of the dependent variable "performance", and it is said that this is not by chance $\left(R^{2}\right.$ adjusted $\left.=30.8 \%\right)$. It could be seen that unstandardized coefficient are $B_{1}=0.208 ; B 2=0.135$ and $B 3=0.100$. Results testify that regression model with the value $F$ $(3,216)=33.496$ it has meaning for $(p=0,00)$ significance $(0,05)$ because in the this case $p=0,000$ is smaller than 0,05 . By statistical test of controlling of the individual regression coefficient, is gotten the same result. $\left(t_{1}=4.972\right)$ and $p_{1}=0,000 ; t_{2}=$ 4.972 and $p_{2}=0,001 ; t_{3}=4.972$ ) and $\left.p_{3}=0,010\right)$. This means that:

$\mathrm{H}_{1}$ hypothesis is accepted.

Next step was to verify the impact of the central and local government policies on the SMEs performance. Government policy was measured with one question so for this reason there was not necessary to realize the factor analysis and the reliability analysis.

To study the impact that government policy has in SMEs was realized the simple regression

$\hat{Y}=\beta_{0}+\beta_{1} x_{1}$

where :,

$\hat{Y}=$ dependet variable "performance"

$x_{1}=$ predictor is "Central and local government policy affects the performance of SMEs " 
Table 5: Regression analyses for the dependet variable "performance"

\begin{tabular}{|l|c|c|c|c|}
\multicolumn{1}{c}{ Model } & $\mathbf{R}^{2}$ & $\mathbf{R}^{2}$ adjusted & $\mathbf{t}$ & Sig \\
\hline (constant) & 0.227 & 0.223 & & \\
Central and local government policy affects the performance of SMEs & & & 7.388 & 0.000 \\
\hline
\end{tabular}

Using the unstandardized regression coefficient, or beta, simple regression equation can be presented as follows:

"performanca"= 2.812+ 0.725 "Central and local government policy affects the performance of SMEs "

Coefficient of the predictor variable in this case " Central and local government policy affects the performance of SMEs " is positive, which means the increase in the level of the independent variable causes the increase in the level of the dependet variable "performancë".

Based on this analyse it results that the independent variable explain $22.3 \%$ of the variance of the dependent variable "performance", and it is said that this is not by chance $\left(\mathrm{R}^{2}\right.$ adjusted $\left.=22.3 \%\right)$. It could be seen that unstandardized coefficient is $B_{1}=0.725$. Results testify that regression model with the value $F(1,219)=63,928$ has meaning for $(p=0,00)$ significance $(0,05)$ because in the this case $p=0,000$ is smaller than 0,05 . By statistical test for controlling of the individual regression was the same result. $(t 1=7,999)$ and $p=0,000)$. This means the $\mathrm{H}_{1}$ hypothesis is accepted.

\section{Conclusions and Recommandations}

The study showed a positive correlation between performance and government policies. This means that supporting policies of the local and central government provide incentives, encouragement to small and medium enterprises. This result is supported even by different researchers who positively evaluate the impact of government policy to SMEs.

- Should be increased the responsibility of local and central government towards small and medium enterprises.

- It's immediate responsibility of government, setting up supporting policies towards new businesses, creating incubators for those businesses, to start, to find the way how to do market research, how to distribute their products, how to manage their experience. Incubators will be a great help for new businesses.

- It is important having policies developed by central and local government to improve the infrastructure, which creates opportunities for businesses. Policies towards setting up incubators will help SMEs to establish their first steps and then to get experience

- Local governments should support not only through various programs but also should work significantly to reduce the informal economy and to open space to grow up formal businesses. Local government and other stakeholders should contribute and work together to promote SMEs in the district, the region and beyond, in order to enhance their image.

- Bringing a continuous assistance through a database for small and medium businesses that will certainly help, and steer for raw materials, sources of supply, of trading, etc.

- Must be built supportive policies on financing businesses, especially those that promise in the future and who want to compete in a highly dynamic and competitive market.

- Businesses need funding for research and development, as it is noted at SMEs, lack of support for research and development will not create possibilities these businesses need financial support to go through success, to go ahead and be succesfull. Offering programs and financial assistance is a very important issue for many SMEs, in order to be able to afford market competition

- The local and national institutions, NGOs, etc., should develop policies to support, to promote and to encourage SMEs. The local government should exercise all its powers against corruption. Also, local government should support formal businesses, and meantime should draw policies and practices to stop growing up the informal businesses In this regard, informality is crucial for all companies that would like to coexist and compete in a highly competitive business environment. A favorable business climate can develop and grow them.

- It's important solving the problem of ownership, in order to increase investment on SMEs.

- To create opportunities to SMEs to expand and extend their activities even in international markets.

- It's important for SMEs to create opportunities and to design policies that will stop migration of businesses from small towns to big ones. Hence, small and medium enterprises should have conditions in their areas to operate. 


\section{References}

Analoui F.,\&Karami A.,(2003), 'Strategic Management'. In small and Medium Enterprises. Thomson Learning 2003.

Bannock G., (1981), 'The economics of Small Firms': Return from the Wilderness, Blackwell, Oxfort.

Field, A., (2005), 'Discovering Statistics using SPSS', SAGE publications, Second.

Hair,J.F., Anderson, R.E.,Tatham, R.L. \& Back,W.C., (1998). Multivariate Data Analysis, Fifth Edition, New Jersey: Prentice Hall.

Hunjra I.A., Jasra M.J.,Khan A.M.,\&Rehman A.R.,(2011), Determinants of business of small and medium enterprises. International Journal of Business and Social Science Vol. 2. No.20 November 2011.

Keskin H.\& Senturk C.,(2010), 'The importance of small and medium - sized enterprises (SME)s in the economies: SWOT analyses of the SME sector in Turkey and Albani,Vol 3, Nr1, fq.116-132.

Naghi M.\&Szasz, L.,(2010). 'Impact of the Romanian industrial sector on the country's ecoomic performance. The Proceedings of the 3rd Internatioanal Conference. Managerial Challenges of the Contemporary Society", Editura Risopring

Schneider, F. and Frey, B. (1985) "Economic and Political Determinants of Foreign Direct Investment," Ëorld Development, vol. 13, pp. 161-175

Sultan S.S.,(2007),Competitive advantage of small and medium sized enterprises: The Case of Jordan's Natural Stone Industry. Maasctricht. 